\title{
APLIKASI EDIBLE COATING MINYAK KAYU MANIS PADA MANISAN TOMAT CHERRY SELAMA PENYIMPANAN
}

\section{APPLICATION OF EDIBLE COATING CINNAMON OIL AS AN ANTIMICROBIAL ON CANDIED CHERRY TOMATOES DURING STORAGE}

\author{
Priska Wisudawaty $^{1)^{*}}$, Indah Yuliasih ${ }^{2)}$, dan Liesbetini Haditjaroko ${ }^{2)}$ \\ 1)Program Studi Teknik Industri, Sekolah Tinggi Teknologi Bandung \\ Jl. Soekarno Hatta No. 378 Bandung 40235; Telp. (022) 5224000 \\ E-mail: priskawisudawaty@yahoo.com \\ ${ }^{2)}$ Departemen Teknologi Industri Pertanian, Fakultas Teknologi Pertanian, Institut Pertanian Bogor \\ Makalah: Diterima 3 Juni 2019; Diperbaiki 20 Januari Oktober 2020; Disetujui 15 Februari 2020
}

\begin{abstract}
Candied cherry tomatoes with antimicrobial edible coatings are one of the alternative product processing technologies that can be developed to maintain the quality and extend shelf life. This study aimed to analyse the effect of antimicrobial edible coating on the cherry tomato quality changes during storage. The experimental design in this study used Completely Randomized Design consists of one factor, namely edible coating which performed twice as replication. The level of treatment test was candied cherry tomatoes without an edible coating, with an edible coating without antimicrobial, and with an antimicrobial edible coating. Based on the analysis of water content, total sugar, total acid, vitamin $C$, total microbe, hardness, and $\mathrm{pH}$, candied cherry tomato with an antimicrobial edible coating was the best treatment. The rate of change water content, total sugar, total acid, vitamin $C$, total microbial, hardness, and $p H$ of the product respectively, were $0.1436,0.3002,0.0058,0.0048$, $690.8838,0.0378,0.0163,10.94$, and $30.07 \%$, respectively. The results of organoleptic tests on aroma, taste, color, and texture showed that $25.71,15.71,65.71$, and $55.71 \%$, respectively, of panelists who like candied cherry tomatoes with antimicrobial edible coatings.
\end{abstract}

Keywords: antimicrobial, candied cherry tomato, cinnamon oil, edible coating

\section{ABSTRAK}

Manisan tomat cherry dengan edible coating antimikroba merupakan salah satu teknologi pengolahan produk alternatif yang dapat dikembangkan untuk menjaga mutu dan memperpanjang umur simpan. Penelitian ini bertujuan untuk menganalisis pengaruh edible coating antimikroba terhadap perubahan mutu manisan tomat cherry selama penyimpanan. Rancangan percobaan dalam penelitian ini menggunakan Rancangan Acak Lengkap (RAL) yang terdiriatassatu faktor yaitu edible coating yang dilakukan sebanyak dua kali ulangan. Taraf perlakuan yang diujikan adalah manisan tomat cherry tanpa edible coating, dengan edible coating tanpa antimikroba, dan dengan edible coating antimikroba. Berdasarkan analisis terhadap kadar air, total gula, total asam, vitamin $\mathrm{C}$, total mikroba, kekerasan, dan $\mathrm{pH}$ diperoleh perlakuan terbaik yaitu manisan tomat cherry dengan edible coating antimikroba. Laju perubahan kadar air, total gula, total asam, vitamin $\mathrm{C}$, total mikroba, kekerasan dan $\mathrm{pH}$, dari produk tersebut secara berturut-turut yaitu 0,$1436 ; 0,3002 ; 0,0058 ; 0,0048 ; 690,8838 ; 0,0378 ; 0,0163 ; 10,94$; 30,07. Hasil uji organoleptik terhadap aroma, rasa, warna, dan tekstur menunjukkan bahwa secara berturut-turut sebanyak 25,$71 ; 15,71 ; 65,71$ dan $55,71 \%$ panelis yang menyukai manisan tomat cherry dengan edible coating antimikroba.

Kata kunci: antimikroba, edible coating, manisan tomat cherry,minyak kayu manis

\section{PENDAHULUAN}

Tomat cherry (Lycopersium esculentum var. cerasiforme) merupakan salah satu komoditas yang berpotensi multiguna, sehingga tomat tergolong sebagai komoditas komersial dan bernilai ekonomi tinggi. Tomat mengandung berbagai vitamin dan senyawa likopen berfungsi sebagai antioksidan dan berguna bagi kesehatan manusia. Vitamin yang banyak terkandung dalam tomat adalah vitamin $\mathrm{C}$ yaitu sekitar 34,38 mg/180 g tomat matang (Sumardiono et al., 2009). Di Indonesia tomat banyak dijual di pasar dengan harga yang relatif murah pada saat panen dan sering kali tidak habis dikonsumsi dalam bentuk segar.

Buah tomat merupakan komoditas yang mudah mengalami kerusakan setelah panen dan tidak tahan lama untuk disimpan, karena setelah dipanen buah tomat terus mengalami perubahan-perubahan akibat adanya pengaruh fisiologis, mekanis, enzimatis dan mikrobiologis. Seperti sayuran lainnya, komponen tertinggi buah tomat adalah air (93-95\%) (Hatmi et al., 2014). Tingginya kadar air dari buah tomat ini, menyebabkan tomat sangat cepat mengalami kerusakan. Daya simpan tomat segar yaitu 3-4 hari. 
Salah satu cara untuk mencegah kerusakan adalah pengolahan tomat cherry menjadi produk dengan kadar air rendah seperti manisan, sehingga pertumbuhan mikroorganisme dapat dicegah (Jayaraman dan Gupta, 2006). Walaupun sudah dibuat manisan, namun ada mikroba yang mampu tumbuh pada $\mathrm{a}_{\mathrm{w}}$ yang rendah seperti khamir Zygosaccharomyces rouxii yang tumbuh pada $\mathrm{a}_{\mathrm{w}} 0,62$ (Deák, 2008). Untuk mempertahankan kualitas produk manisan tomat cherry tersebut dapat dilakukan dengan memanfaatkan edible coating antimikroba.

Edible coating dapat terbuat dari beberapa jenis bahan, salah satunya adalah berbasis pati seperti tapioka. Penambahan antimikroba pada edible coating bertujuan untuk menghambat pertumbuhan dan aktivitas mikroba, sehingga dapat meningkatkan umurs impan produk. Kayu manis merupakan salah satu rempah yang memiliki sifat anti mikroba alami, karena mengandung sinamaldehid yang bersifat sebagai antibakteri sebesar 60-75\% (Wang et al., 2005).

Berdasarkan berbagai informasi tersebut, edible coating minyak kayu manis sebagai antimikroba diharapkan dapat digunakan untuk memperpanjang umur simpan manisan tomat cherry. Tujuan dari penelitian ini adalah untuk menganalisis pengaruh edible coating antimikroba terhadap perubahan mutu manisan tomat cherry selama penyimpanan.

\section{METODE PENELITIAN}

\section{Bahan dan Alat}

Bahan yang digunakan dalam penelitian ini adalahtomat cherry dengan warna merah kehijauan dan bentuk lonjong yang diperoleh dari PangalenganBandung, tapioka cap Pak Tani, dan minyak kayu manis. Bahan lainnya yang digunakan adalah gliserol, akuades, gula pasir curah, garam merk Refina, $\mathrm{CaCO}_{3}$, asam stearat, dan bahan kimia lainnya untuk keperluan analisis.

Peralatan yang digunakan adalah mesin pengering rak (tray dryer), inkubator, buret, oven, penangas, magnetic stirrer, gelas piala, gela sukur, sudip, cawan petri, gegep, tabung reaksi, tip pipet, jarum ose, otoklaf, viskosimeter, dan alat lainnya.

\section{TahapanPenelitian}

\section{Edible Coating Antimikroba}

Pembuatan dan formulasi edible coating tapioka diawali dengan membuat suspense tapioka $3 \%(\mathrm{~b} / \mathrm{v})$ dipanaskan pada suhu $70^{\circ} \mathrm{C}$ hingga terjadi gelatinisasi. CMC $0,4 \%$ (b/v) dilarutkan kedalam larutan tapioka tersebut sambil diaduk selama 3 menit sampai homogen, kemudian ditambahkan gliserol 5\% (v/v) untuk meningkatkan elastisitas lapisan. Setelah semuanya larut dan homogen, ditambahkan asam stearat $0,5 \%(\mathrm{~b} / \mathrm{v})$ dan tetap diaduk sampai homogen. Proses selanjutnya yaitu pendinginan ediblecoating pada suhu $40^{\circ} \mathrm{C}$. Setelah itu, minyak kayu manis sebagai antimikroba ditambahkan sesuaik onsentrasi, yaitu 0 dan $0,6 \%$ (v/v) (Wisudawaty et al., 2016).

\section{Pembuatan Manisan Tomat Cherry dan Analisis Perubahan Mutu Manisan Tomat Cherry Selama Penyimpanan}

Pembuatan manisan tomat cherry dimulai dengan sortasi untuk memisahkan tomat yang busuk selanjutnya dibuang bagian daun ujungnya lalu dicuci dengan air mengalir. Perendaman pertama dilakukan dengan menggunakan larutan garam $1 \%$ selama 30 menit (Windyastari et al., 2007). Perendaman kedua menggunakan larutan $\mathrm{CaCO}_{3} 1 \%$ selama 30 menit dengan penanganan bentuk buah utuh dan dikerat silang. Setelah dilakukan perendaman, selanjutnya tomat cherry dibilas dengan air mengalir, lalu direndam dengan larutan gula pada kombinasi 40-55$70 \% \mathrm{~b} / \mathrm{v}$ dengan lama perendaman 12 jam untuk masing-masing konsentrasi (Wisudawaty et al., 2016). Pengeringan dilakukan dengan bantuan alat pengering rak (tray drayer) pada suhu $\pm 50^{\circ} \mathrm{C}$ selama 27 jam. Setelah itu edible coating antimikroba diaplikasikan ke manisan tomat cherry dengan menggunakan metode celup. Kemudian dilakukan pengeringan kembali pada suhu $\pm 50{ }^{\circ} \mathrm{C}$ selama 6 jam, lalu dilakukan pengemasan dalam wadah PET dan disimpan pada suhu $30^{\circ} \mathrm{C}$ selama 12 minggu. Pengujian yang dilakukan meliputi total mikroba, kelunakan, $\mathrm{pH}$, total asam, total gula, vitamin $\mathrm{C}$, dan organoleptik.

\section{Analisis Total Mikroba}

Prinsip metode TPC (total mikroba) adalah sel khamir dalam sampel ditumbuhkan pada medium agar dan diinkubasi selama 24-48 jam. Sel khamir akan tumbuh membentuk koloni yang dapat dipelihara secara visual sehingga dapat langsung dihitung. Prosedur pengujian total mikroba pertamatama cawan petri, tabung reaksi dan tip pipet disterilisasi dalam oven pada suhu $180^{\circ} \mathrm{C}$. Sampel sebanyak $1 \mathrm{~g}$ ditimbang dan dihancurkan, kemudian secara aseptis sampel dimasukkan ke dalam tabung reaksi yang berisi larutan pengencer $9 \mathrm{~mL}$. Setelah dikocok, diambil dengan pipet steril $1 \mathrm{~mL}$ untuk pengenceran berikutnya. Selanjutnya sebanyak $1 \mathrm{~mL}$ sampel yang telah diencerkan sampai pada tingkat tertentu diambil dengan pipet steril secara aseptis, dan dipindahkan ke dalam cawan petri. Media PDA steril dengan suhu sekitar $45^{\circ} \mathrm{C}$ dituang ke dalam cawan petri kemudian digerakkan di atas meja dengan gerakan melingkar agar media merata. Setelah media membeku, cawan petri diinkubasi dengan posisi terbalik dalam inkubator pada suhu $37^{\circ} \mathrm{C}$ selama 24 48 jam. Setelah waktu inkubasi, koloni yang tumbuh pada cawan petri dapat dihitung dengan jumlah koloni yang diterima 30-300 koloni per cawan (Harianingsih, 2010). Nilai TPC dihitung dengan menggunakan rumus : Koloni per $\mathrm{mL}$ atau per $\mathrm{g}=$ Jumlah koloni per cawan + (1:faktor pengenceran). 


\section{Analisis Total Asam}

Proseduranalisis total asam yaitu sebanyak $100 \mathrm{~g}$ bahan yang sudah dihancurkan dalam blender. Kemudian dimasukkan dalam labu ukur $250 \mathrm{~mL}$, encerkan sampai tanda tera dengan menambah air destilata yang digunakan sebagai pembilas blender, selanjutnya disaring menggunakan kertas saring. Filtrat sebanyak $25 \mathrm{~mL}$ dimasukkan ke dalam erlenmeyer dan ditambah indikator pp sebanyak 3 tetes, kemudian dititrasi dengan larutan $\mathrm{NaOH} 0,1 \mathrm{~N}$ sampai timbul warna merah muda yang stabil. Total asam tertitrasi dinyatakan sebagai $\mathrm{NaOH} 0,1 \mathrm{~N}$ per $100 \mathrm{~g}$ bahan. Total asam tertitrasi dihitung dengan rumus :

Total asam $=\underline{(\mathrm{mL} \mathrm{NaOH} \times \mathrm{N} \mathrm{NaOH}}) \times$ fp $\times \mathrm{BE} \times 100 \%$ Bobot bahan $\mathrm{x} 1000$

Keterangan:

$\mathrm{N}$ : normalitas larutan $\mathrm{NaOH}$

$\mathrm{fp}$ : faktor pengencer

$\mathrm{BE}$ : bobot ekuivalen asam malat

\section{Analisis Vitamin C}

Prosedur analisis vitamin $\mathrm{C}$ yaitu sebanyak $100 \mathrm{~g}$ bahan yang sudah dihancurkan dalam blender. Kemudian dimasukkan dalam labu ukur $250 \mathrm{~mL}$, encerkan sampai tanda tera dengan menambah air destilata yang digunakan sebagai pembilas blender, selanjutnya disaring menggunakan kertas saring. Filtrat yang diperoleh sebanyak $25 \mathrm{~mL}$ dimasukkan ke dalam erlenmeyer, ditambahkan 2-3 tetes pati $1 \%$, kemudian dititrasi dengan larutan iod 0,01 N sampai timbul perubahan warna yang stabil (biru ungu). Setiap $\mathrm{mL}$ iod sebanding dengan $0,88 \mathrm{mg}$ asam askorbat. Setiap $\mathrm{ml}$ iod sebanding dengan $0,88 \mathrm{mg}$ asam askorbat, sehingga kadar asam askorbat (vitamin C) dari bahan dapat dihitung dengan rumus:

Kadar asam askorbat $(\mathrm{mg} / 100 \mathrm{~g}$ bahan $)=$ $\underline{\mathrm{mL} \operatorname{iod} \times 0,01 \mathrm{~N} \times 0,88 \times \mathrm{fp} \times 100 \%}$ berat contoh

Keterangan:

fp : faktor pengencer

\section{Analisis Total Gula}

Prosedur analisis total gula dimulai dengan larutan contoh sebanyak $2 \mathrm{~mL}$ dipipet ke dalam tabung reaksi, larutan phenol 5\% sebanyak $1 \mathrm{~mL}$ ditambahkan dan dikocok. Larutan $\mathrm{H}_{2} \mathrm{SO}_{4}$ pekat sebanyak $5 \mathrm{~mL}$ ditambahkan dengan cara menuangkan secara tegak lurus permukaan larutan. Larutan didiamkan selama 10 menit, dikocok lalu disimpan pada suhu ruang selama 15 menit. Setelah itu dipindahkan ke dalam kuvet dan dibaca nilai absorbannya pada panjang gelombang $490 \mathrm{~nm}$, lalu dibuat kurva hubungan antara absorbansi dengan ppm gula.

\section{Rancangan Percobaan}

Rancangan percobaan yang digunakan adalah Rancangan Acak Lengkap (RAL) yang terdiri atas satu faktor yaitu edible coating yang dilakukan sebanyak dua kali ulangan. Taraf perlakuan yang diujikan adalah manisan tomat cherry tanpa edible coating, dengan edible coating tanpa antimikroba, dan dengan edible coating antimikroba. Model matematika yang digunakan yaitu:

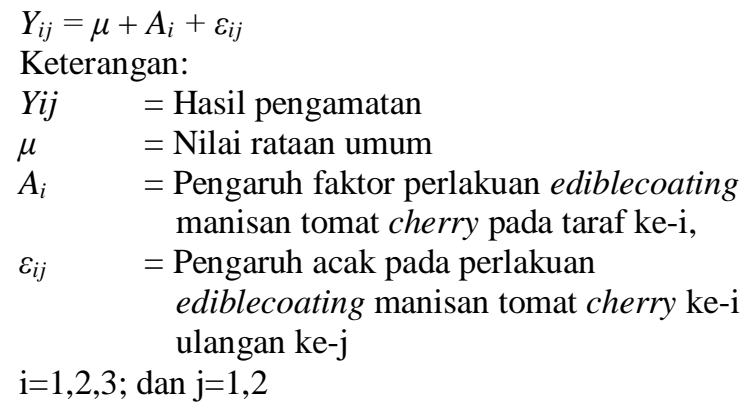

\section{HASIL DAN PEMBAHASAN}

\section{Aplikasi Edible Coating pada Manisan Tomat Cherry \\ Manisan tomat cherry yang telah dilapisi} edible coating disimpan selama 12 minggu untuk mengetahui perubahan mutu yang terjadi. Pengujian total mikroba, total gula, kekerasan, $\mathrm{pH}$, total asam, vitamin $\mathrm{C}$ dan organoleptik dilakukan selama penyimpanan. Adapun perlakuan yang diaplikasikan diantaranya perlakuan edible coating (tanpa edible coating, edible coating tanpa antimikroba, dan edible coating antimikroba).

Total mikroba merupakan salah satu parameter penentu mutu dari suatu produksi atau makanan. Total mikroba yang terkandung pada produk pangan akan mengalami peningkatan selama penyimpanan. Nilai total mikroba manisan tomat cherry erat kaitannya dengan laju perubahan total gula. Gula pada manisan tomat cherry selain berfungsi memberikan rasa manis juga melindungi permukaan daging tomat cherry dari kontak langsung dengan oksigen sehingga dapat mencegah terjadinya kerusakan pigmen likopen (Mu'nisa, 2012). Hubungan laju perubahan total gula dan total mikroba manisan tomat cherry selama penyimpanan dapat dilihat pada Gambar 1.

Pada Gambar 1, terlihat bahwa peningkatan total mikroba berbanding terbalik dengan penurunan total gula manisan tomat cherry selama penyimpanan. Penurunan total gula selama penyimpanan terjadi karena aktivitas dan pertumbuhan mikroba (total mikroba dan total khamir) meningkat sangat signifikan. Mikroorganisme memanfaatkan gula untuk pertumbuhannya. 

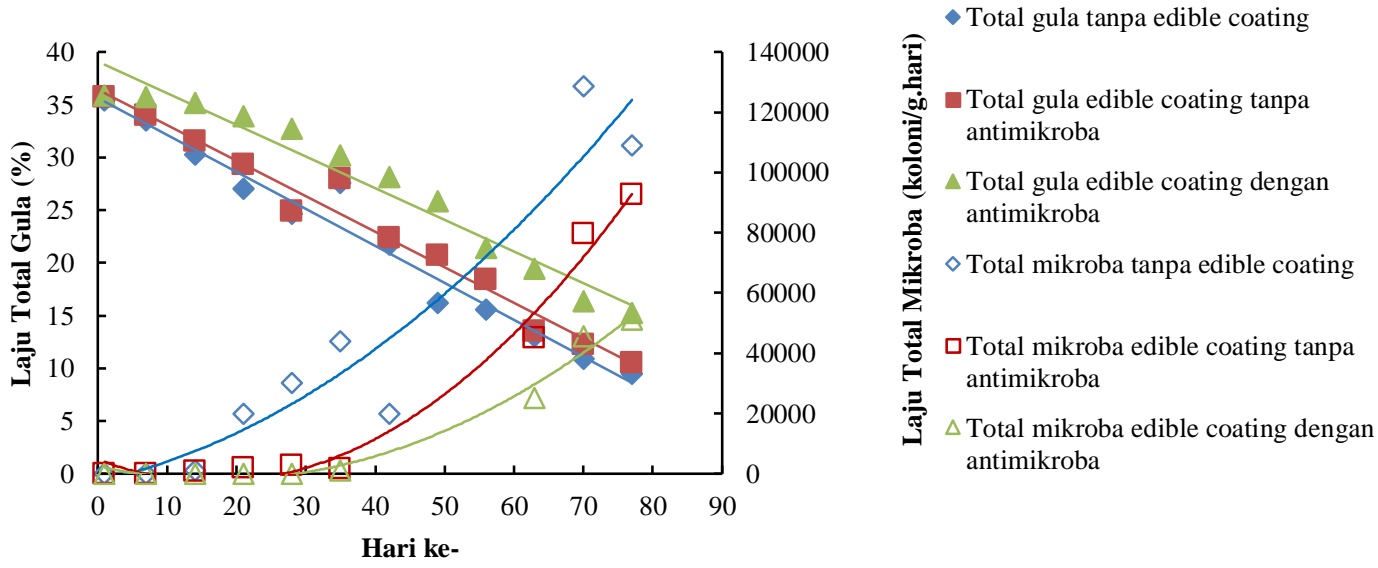

Gambar 1. Hubungan laju perubahan total gula dan total mikroba manisan tomat cherry selama penyimpanan

Umumnya mikroba yang tumbuh pada bahan pangan menggunakan senyawa organik sebagai sumber energi dan sumber karbon (Safitri et al., 2016). Bahan-bahan pangan yang mengandung karbohidrat dengan bobot molekul rendah (misalnya mono dan disakarida seperti glukosa, fruktosa dan sukrosa) secara alami kurang selektif terhadap pertumbuhan mikroba karena banyak jenis mikroba yang dapat menggunakan jenis-jenis gula tersebut (Buckle et al., 2010).

Analisis ragam menunjukkan bahwa perlakuan edible coating (tanpa edible coating, dengan edible coating tanpa antimikroba, dan dengan edible coating antimikroba) yang diaplikasikan pada manisan tomat cherry memberikan pengaruh nyata terhadap perubahan total gula dan total mikroba manisan tomat cherry selama penyimpanan. Demikian pula berdasarkan uji lanjut DMRT (Duncan's Multiple Range Test) pada tingkat kepercayaan $95 \%(\alpha=0,05)$. Produk manisan tomat cherry dengan edible coating antimikroba memiliki laju penurunan total gula dan peningkatan total mikroba terendah, yakni $0,3002 \%$ dan 690,8838 koloni/g.hari. Hal itu diduga senyawa antimikroba seperti sinamaldehid yang terdapat dalam minyak kayu manis dapat menghambat pertumbuhan khamir Zygosaccharomyces rouxii selama penyimpanan. Penurunan total gula selama penyimpanan disebabkan oleh pemecahan gula oleh mikroba menjadi alkohol, karbohidrat, asam asetat, dan asam laktat (Sartika, 2010). Untuk dapat mempertahankan hidupnya, mikroba membutuhkan makan atau energi yang diduga sebagian besar berasal dari gula yang terdapat pada manisan. Hal inilah yang menyebabkan menurunnya total gula pada manisan tomat cherry.

Peningkatan kadar air selama penyimpanan akan memengaruhi kelunakan manisan tomat cherry. Kelunakan adalah gaya yang dibutuhkan untuk menekan suatu bahan atau produk sehingga terjadi perubahan produk yang diinginkan. Kelunakan manisan tomat cherry diukur dengan menggunakan penetrometer dengan prinsip bahwa semakin besar jarak penembusan probe $(\mathrm{mm} / \mathrm{s})$, maka nilai kelunakan semakin bertambah (Nurdjanah et al., 2007). Hubungan laju perubahan kelunakan dan kadar air manisan tomat cherry selama penyimpanan dapat dilihat pada Gambar 2.

Pada Gambar 2 terlihat bahwa peningkatan kelunakan berbanding lurus dengan peningkatan kadar air manisan tomat cherry selama penyimpanan. Analisis ragam menunjukkan bahwa perlakuan edible coating (tanpa edible coating, dengan edible coating tanpa antimikroba, dan dengan edible coating antimikroba) yang diaplikasikan pada manisan tomat cherry memberikan pengaruh nyata terhadap perubahan kadar air dan kelunakan manisan tomat cherry selama penyimpanan. Demikian pula berdasarkan uji lanjut DMRT (Duncan's Multiple Range Test) yang dilakukan pada tingkat kepercayaan $95 \%(\alpha=0,05)$. Produk manisan tomat cherry dengan edible coating antimikroba memiliki laju peningkatan kelunakan dan kadar air terendah, yakni $0,0378 \mathrm{~mm} / \mathrm{s}$ dan $0,1436 \%$, sedangkan manisan tomat cherry tanpa edible coating memiliki laju peningkatan tertinggi, yakni $0,0856 \mathrm{~mm} / \mathrm{s}$ dan $0,2390 \%$. Hal ini disebabkan pelapisan dengan edible coating antimikroba mampu menghambat absorbs uap air dari udara yang RHnya tinggi ke produk kering. Hal ini sesuai dengan pernyataan Hasanah (2009) bahwa pelunakan produk berhubungan langsung dengan berkurangnya kadar air dalam produk. Selain itu, adanya coating akan membatasi kontak permukaan produk dengan oksigen yang selanjutnya akan mengurangi aktivitas enzim poligalakturonase dan amilase sehingga protopektin dan pati tidak terlalu didegradasi menjadi pektin yang larut air.

Menurut Santoso et al. (2004) coating dapat memperlambat proses terjadinya sineresis, selain itu dapat menghambat penetrasi gas oksigen karena matriks coating mempunyai ikatan yang kuat, rapat, dan kompak yang menyebabkan permeabilitas gas rendah. Menurut Agus et al. (2007) tekstur manisan tomat menjadi lunak terutama disebabkan oleh perubahan yang terjadi pada dinding sel dan substansi pektin secara progresif menyebabkan proses perombakan polisakarida dan penyusun dinding sel 
berjalan cepat. Dengan semakin besarnya polisakarida yang terombak maka tekstur akan semakin lunak.

Peningkatan kadar air selama penyimpanan juga akan memengaruhi laju penurunan vitamin $\mathrm{C}$ manisan tomat cherry. Pada Gambar 3, terlihat bahwa peningkatan kadar air berbanding terbalik dengan penurunan konsentrasi vitamin $\mathrm{C}$ manisan tomat cherry selama penyimpanan. Penurunan konsentrasi vitamin Cmanisan tomat cherry tanpa edible coating, dengan edible coating tanpa antimikroba, dan dengan edible coating antimikroba secara berturut-turut adalah 60,58 , dan $49 \%$.

Analisis ragam menunjukkan bahwa perlakuan edible coating (tanpa edible coating, dengan edible coating tanpa antimikroba, dan dengan edible coating antimikroba) yang diaplikasikan pada manisan tomat cherry memberikan pengaruh nyata terhadap perubahan kadar air dan konsentasi vitamin C manisan tomat cherry selama penyimpanan. Demikian pula berdasarkan uji lanjut DMRT dengan tingkat kepercayaan $95 \%(\alpha=0,05)$. Produk manisan tomat cherry dengan edible coating antimikroba

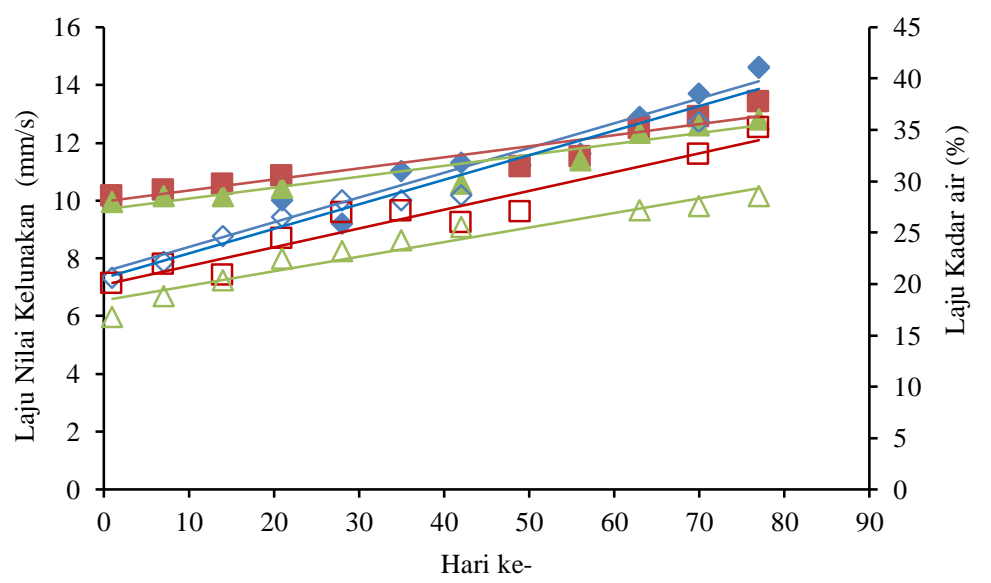

memiliki laju perubahan konsentrasi vitamin $\mathrm{C}$ dan kadar air terendah, yakni $0,0048 \mathrm{mg} / 10 \mathrm{~g}$ bahan dan $0,1436 \%$. Hal itu diduga disebabkan oleh karakteristik edible coating antimikroba yang lebih stabil. Kestabilan tinggi pada edible coating yang digunakan akan membuat lapisan coating yang terbentuk menjadi lebih kompak dan padat, sehingga kemampuan sebagai barrier terhadap uap air semakin meningkat yang menyebabkan penurunan konsentrasi vitamin $\mathrm{C}$ dapat dihambat. Begitu juga manisan tomat cherry dengan edible coating tanpa antimikroba memiliki laju terkecil berikutnya, hal itu diduga disebabkan karena edible coating yang diaplikasikan pada manisan tomat cherry efektif sebagai barrier dalam menghambat uap air sehingga oksigen dapat mengoksidasi vitamin $\mathrm{C}$, sedangkan manisan tomat cherry tanpa edible coating memiliki laju penurunan konsentrasi vitamin $\mathrm{C}$ terbesar, hal itu diduga disebabkan karena tidak memiliki barrier pada permukaan, sehingga transmisi uap air akan semakin mudah terjadi yang mengakibatkan vitamin $\mathrm{C}$ semakin mudah larut dalam air.

- Kelunakan tanpa edible coating

- Kelunakan edible coating tanpa antimikroba

$\triangle$ Kelunakan edible coating dengan antimikroba

$\diamond$ Kadar air tanpa edible coating

$\square$ Kadar air edible coating tanpa antimikroba

$\triangle$ Kadar air edible coating dengan antimikroba

Gambar 2. Hubungan laju perubahan kelunakan dan kadar air manisan tomat cherry selama penyimpanan

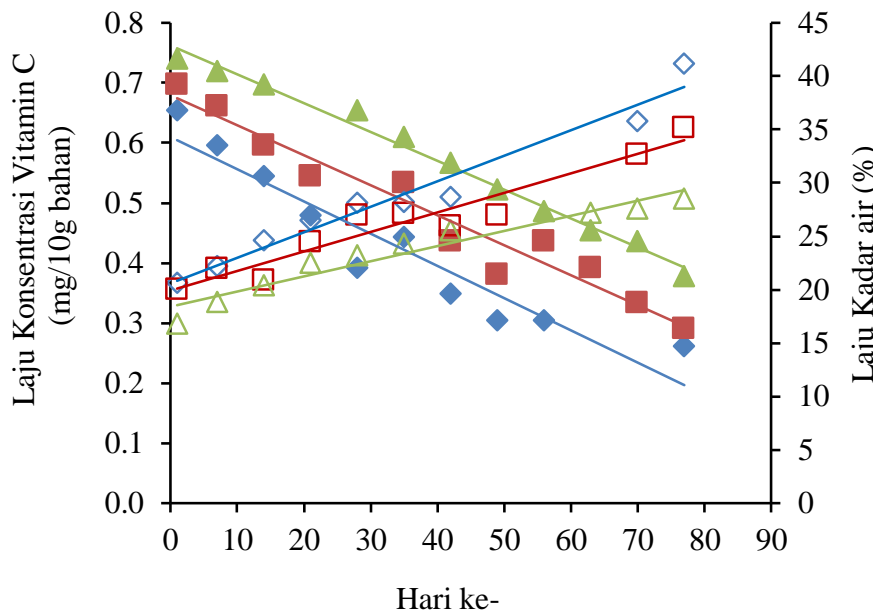

$\diamond$ Vitamin C tanpa edible coating

Vitamin C edible coating tanpa antimikroba

$\triangle$ Vitamin $\mathrm{C}$ edible coating dengan antimikroba

$\diamond$ Kadar air tanpa edible coating

$\square$ Kadar air edible coating tanpa antimikroba

$\triangle$ Kadar air edible coating dengan antimikroba

Gambar 3. Hubungan laju perubahan vitamin C dan kadar air manisan tomat cherry selama penyimpanan 
Menurut Helmiyesi et al. (2008) dan Ersoy et al. (2011) penyimpanan produk dalam suhu ruang, penguapan air menyebabkan struktur sel yang semula utuh menjadi layu, sehingga enzim askorbat oksidase akan dibebaskan dengan cara kontak langsung dengan asam dan akibatnya vitamin $\mathrm{C}$ mengalami penurunan atau kerusakan. Selain itu, vitamin $\mathrm{C}$ sangat mudah larut dalam air (Begum et al., 2008). Selama proses pembuatan manisan tomat cherry, vitamin C mengalami kerusakan cukup banyak, terutama pada saat pencucian dengan air mengalir dan proses pengeringan.

Selama penyimpanan peningkatan total asam sangat berkaitan dengan nilai $\mathrm{pH}$ manisan tomat cherry. Total asam merupakan ukuran dari keseluruhan asam yang terdapat pada suatu bahan, sedangkan $\mathrm{pH}$ adalah derajat keasaman. Pada Gambar 4, terlihat bahwa peningkatan total asam seiring dengan penurunan $\mathrm{pH}$ manisan tomat cherry selama penyimpanan.

Analisis ragam menunjukkan bahwa perlakuan edible coating (tanpa edible coating, dengan edible coating tanpa antimikroba, dan dengan edible coating antimikroba) yang diaplikasikan pada manisan tomat cherry memberikan pengaruh nyata terhadap perubahan total asam dan $\mathrm{pH}$ manisan tomat cherry selama penyimpanan. Demikian pula berdasarkan uji lanjut DMRT (Duncan's Multiple Range Test) yang dilakukan pada tingkat kepercayaan $95 \%(\alpha=0,05)$. Produk manisan tomat cherry dengan edible coating antimikroba memiliki laju peningkatan total asam dan penurunan $\mathrm{pH}$ terendah, yakni $0,0058 \%$ /hari dan 0,0163 . Hal itu diduga disebabkan karena adanya senyawa antimikroba minyak kayu manis yang dapat menghambat aktivitas khamir selama penyimpanan seperti senyawa sinamaldehid yang dapat menyebabkan denaturasi protein sel dan merusak membran sel (Rodriguez et al., 2008). Peningkatan total asam pada manisan tomat cherry selama penyimpanan diduga disebabkan karena konversi gula menjadi asam organik. Menurut Toor et al. (2006) total asam tertitrasi yang tinggi mempengaruhi terhadap stabilnya kandungan asam askorbat pada produk.

\section{Organoleptik \\ Organoleptik merupakan uji yang bersifat} subektif. Uji organoleptik digunakan untuk mengetahui tingkat kesukaan konsumen terhadap suatu produk (Wisudawaty et al., 2012). Uji ini menggunakan panelis yang mempunyai tingkat kesukaan dan kepekaan yang bervariasi. Panelis yang dipakai dalam pengujian adalah panelis terlatih dengan jumlah 10 orang. Uji organoleptik dilakukan setiap dua minggu sekali. Dalam uji ini panelis diminta mengungkapkan tanggapan subjektif tentang kesukaan atau ketidaksukaan dengan menggunakan skala hedonik.

\section{Aroma}

Aroma adalah bau yang ditimbulkan oleh rangsangan kimia yang tercium oleh syaraf-syaraf olfaktori yang berada dalam rongga hidung ketika makanan masuk ke dalam mulut. Grafik perubahan \% kesukaan panelis terhadap aroma manisan tomat cherry selama penyimpanan dapat dilihat pada Gambar 5. Pada umumnya, panelis yang suka terhadap aroma manisan tomat cherry menurun selama penyimpanan. Pada hari ke-1 sampai ke-35 penyimpanan, tingkat kesukaan panelis terhadap aroma masih tinggi yang artinya manisan tomat cherry belum terlalu mengalami perubahan komponen di dalam buah, sehingga aromanya tetap harum khas tomat. Pada hari ke-49 dan ke-63 banyak panelis yang tidak suka terhadap aroma manisan tomat cherry, kesukaan panelis tidak mencapai $50 \%$. Pada hari ke-77, masih terdapat manisan tomat cherry yang disukai oleh panelis yaitu perlakuan A3 (dengan edible coating antimikroba), namun itu juga tidak lebih dari 50\% panelis yang suka terhadap aromanya. Aroma manisan tomat cherry sudah tidak layak sejak hari ke-49 penyimpanan.

Selama penyimpanan tingkat kesukaan panelis terhadap manisan tomat cherry semakin menurun. Penurunan ini disebabkan karena aroma khas dari tomat ikut hilang atau menguap pada saat proses pengeringan pembuatan manisan. Hal ini sesuai dengan pernyataan Suprapti (2003), bahwa aroma merupakan unsur yang sangat peka terhadap perlakuan pemanasan pada suhu tinggi, oleh karena itu sulit dipertahankan.

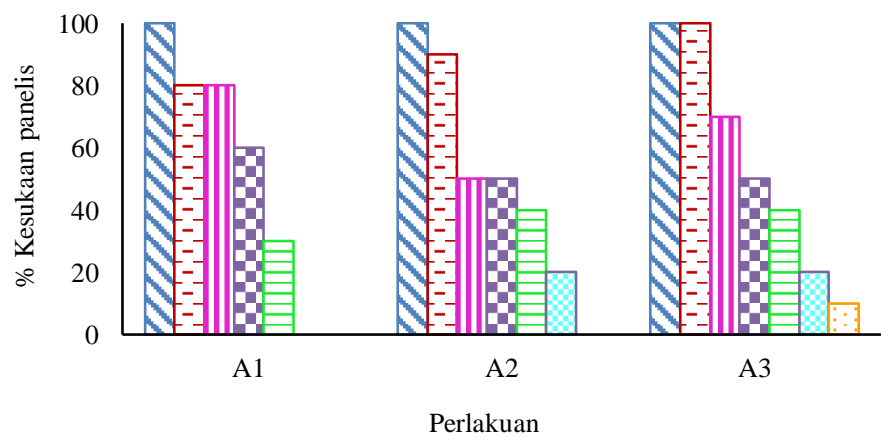

$\checkmark$ Hari ke-1

$\square$ Hari ke-7

m Hari ke-21

$\square$ Hari ke-35

$\boxminus$ Hari ke-49

$\square$ Hari ke-63

$\square$ Hari ke-77

Perlakuan

Gambar 5. Perubahan \% kesukaan panelis terhadap aroma manisan tomat cherry selama penyimpanan 
Penurunan jumlah panelis yang suka terhadap aroma berkaitan dengan uji kimia dari manisan tomat cherry yang berupa total asam tertitrasi. Selama penyimpanan, asam asetat pada manisan tomat cherry mengalami peningkatan yang dapat menyebabkan timbulnya aroma yang asam sehingga kesukaan panelis terhadap aroma produk menurun.

\section{Rasa}

Rasa adalah tingkat kesukaan panelis dari manisan tomat cherry yang diamati dengan indera perasa. Rasa yang dihasilkan adalah sedikit rasa khas tomat cherry dan rasa manis sebagai akibat penambahan gula. Grafik \% kesukaan panelis dapat dilihat pada Gambar 6. Pada gambar tersebut terlihat bahwa tingkat kesukaan panelis terhadap rasa mengalami penurunan yang signifikan. Pada manisan tomat cherry tanpa edible coating (A1) di hari penyimpanan ke-35 masih disukai oleh panelis, sedangkan untuk manisan tomat cherry dengan edible coating tanpa antimikroba (A2) maupun dengan antimikroba (A3) pada hari ke-21 banyak panelis yang tidak suka terhadap rasa manisan tomat cherry, kesukaan panelis tidak mencapai 50\%. Pada hari ke77 penyimpanan, hanya perlakuan manisan tomat cherry tanpa edible coating dan dengan edible coating tanpa antimikroba yang masih disukai oleh panelis, dan tidak lebih dari 50\%, sedangkan pada manisan tomat cherry dengan edible coating antimikroba sudah tidak disukai oleh panelis pada hari ke-77 penyimpanan. Penurunan rasa yang signifikan pada manisan tomat cherry dengan edible coating antimikroba (A3) dimungkinkan masih tersisanya minyak kayu manis yang menempel pada produk, sehingga after taste minyak kayu manisnya masih kuat.
Penurunan rasa selama penyimpanan dipengaruhi oleh sifat kimianya seperti total gula, vitamin $\mathrm{C}$ dan total asam yang terdapat dalam produk. Selama penyimpanan, total gula yang ada dalam produk mengalami penurunan akibat dikonsumsi oleh mikroba yang menyebabkan rasa manisan tomat cherry menurun tingkat kemanisannya. Begitu juga yang terjadi dengan nilai total asam tertitrasi. Kandungan asam sitrat yang merupakan salah satu sumber cita rasa produk semakin lama semakin menurun, sedangkan asam asetat semakin lama semakin meningkat. Kandungan vitamin $\mathrm{C}$ yang menurun pada produk juga menyebabkan rasa produk menjadi kurang disukai oleh panelis.

\section{Warna}

Warna menjadi parameter fisik yang sering digunakan konsumen sebagai ukuran baik tidaknya sebuah produk. Warna dapat memengaruhi persepsi seseorang terhadap flavor suatu produk (Garber et al., 2000). Pada Gambar 7, terlihat bahwa tingkat kesukaan panelis terhadap warna mengalami penurunan selama penyimpanan. Penurunan tingkat kesukaan panelis terhadap warna disebabkan oleh terjadinya degradasi likopen pada produk. Degradasi likopen dapat melalui proses isomerasi dan oksidasi karena cahaya, oksigen, suhu tinggi, teknik pengeringan, proses pengelupasan, penyimpanan dan asam (Febriansah dan Luthfia, 2009). Proses pengeringan memegang peranan yang sangat penting, jika suhu pengeringan terlalu tinggi akan mengakibatkan penurunan nilai gizi dan perubahan warna produk yang dikeringkan. Warna yang dihasilkan manisan tomat cherry adalah merah kecokelatan.

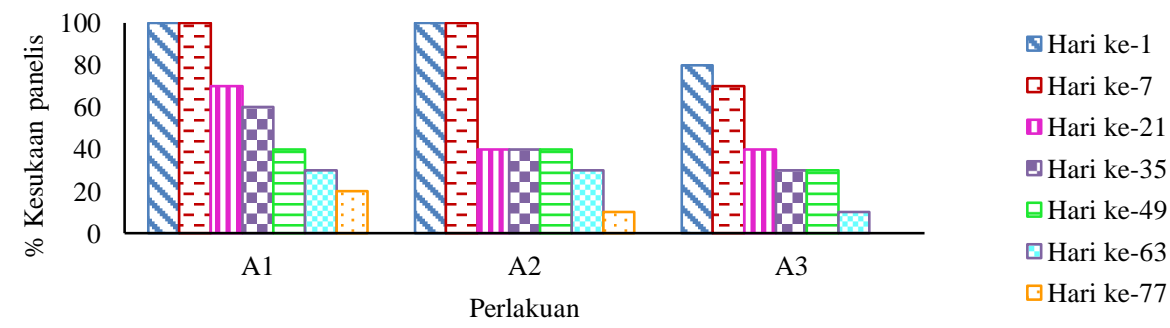

Gambar 6. Perubahan \% kesukaan panelis terhadap rasa manisan tomat cherry selama penyimpanan

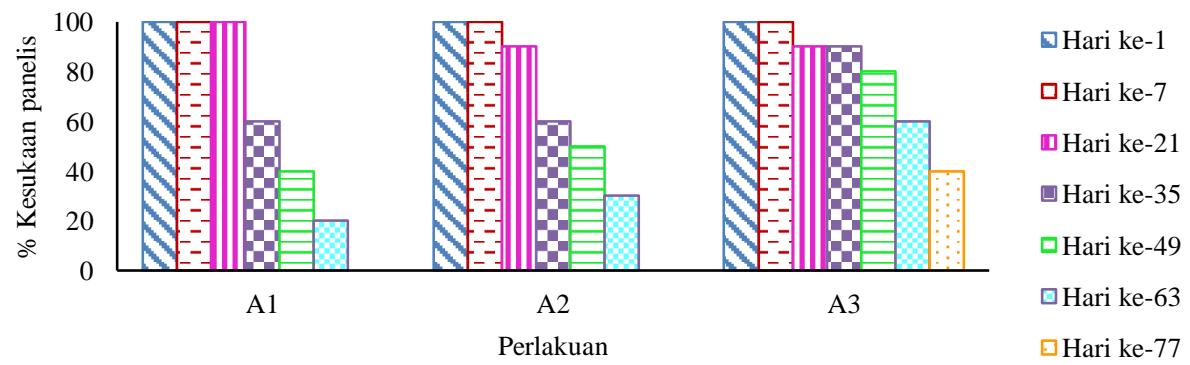

Gambar 7. Perubahan \% kesukaan panelis terhadap warna manisan tomat cherry selama penyimpanan 
Menurut Febriyanti et al. (2018) menyatakan bahwa reaksi pencokelatan bahan makanan yang mengandung karbohidrat dapat dipercepat oleh pengaruh pemasakan sehingga komponen gula pereduksi akan membentuk senyawa berwarna cokelat. Perlakuan terbaik yaitu pada manisan tomat cherry dengan edible coating antimikroba. Hal tersebut menunjukkan bahwa perlakuan edible coating antimikroba pada manisan tomat cherry mampu memperlambat perubahan warna menjadi merah kecokelatan dan berpengaruh pada kesukaan panelis terhadap parameter warna. Edible coating mampu memperbaiki penampilan dengan meningkatkan kilap pada produk dan mempertahankan warna produk. Panelis cenderung menyukai produk manisan yang memiliki warna merah dan agak mengkilap.

\section{Tekstur}

Tekstur merupakan sifat fisik dari bahan pangan yang penting. Hal ini mempunyai hubungan dengan rasa pada waktu mengunyah bahan tersebut. Salah satu cara penentuan tekstur suatu bahan pangan adalah memberikan beban terhadap bahan tersebut misalnya dengan pemeriksaan tekanan jari. Pada Gambar 8, terlihat bahwa kesukaan panelis terhadap tekstur manisan tomat cherry mengalami penurunan. Pada hari ke-1 sampai ke-35, tingkat kesukaan panelis terhadap warna masih tinggi. Penurunan tajam dimulai pada hari ke-49 penyimpanan. Pada hari ke63 penyimpanan, perlakuan A3 (dengan edible coating antimikroba) masih memiliki tingkat kesukaan yang tinggi yaitu mencapai 50\%, sedangkan untuk perlakuan A1 dan A2 kesukaan panelis tidak mencapai $50 \%$.

Semakin lama penyimpanan tingkat kesukaan panelis terhadap tekstur manisan tomat cherry semakin menurun. Manisan tomat cherry semakin lama waktu penyimpanan maka memiliki tekstur yang lunak. Hal ini berkaitan dengan nilai kadar air, dimana semakin lama waktu penyimpanan maka kadar air produk semakin meningkat, sehingga tekstur manisan tomat cherry menjadi lunak. Tekstur manisan yang lembek/lunak disebabkan terjadinya penurunan ketegangan dinding sel karena air berdifusi keluar sel. Menurut Agus et al. (2007) tekstur manisan tomat menjadi lunak terutama disebabkan oleh perubahan yang terjadi pada dinding sel dan substansi pektin secara progresif menyebabkan proses perombakan polisakarida dan penyusun dinding sel berjalan cepat. Dengan semakin besarnya polisakarida yang terombak maka tekstur akan semakin lunak.

\section{KESIMPULANDAN SARAN}

\section{Kesimpulan}

Hasil pengujian selama umur simpan produk menunjukkan bahwa terjadi penurunan mutu produk selama penyimpanan. Kandungan total asam, total mikroba, dan kekerasan manisan tomat cherry mengalami peningkatan selama penyimpanan yaitu berturut-turutsebesar $0,0058-0,0076 \%$ per hari, 690,8838-1.688,3601 koloni/g.hari, dan 0,0378$0,0856 \mathrm{~mm} / \mathrm{s}$ per hari, sedangkan kandungan total gula, vitamin $\mathrm{C}$, dan $\mathrm{pH}$ manisan tomat cherry mengalami penurunan selama penyimpanan yaituberturut-turut sebesar 0,3002-0,3508\% per hari, 0,0048-0,0058 mg/10 g bahan per hari, dan 0,01630,0373 per hari.

Berdasarkan analisis terhadap total gula, total asam, vitamin $\mathrm{C}$, total mikroba, kekerasan, dan $\mathrm{pH}$ diperoleh perlakuan terbaik yaitu manisan tomat cherry dengan edible coating antimikroba. Kandungan total gula, total asam, vitamin C, total mikroba, kelunakan, dan $\mathrm{pH}$ dari produk tersebut secara berturut-turut yaitu $20,54 \% ; 0,84 \%$ per hari; 0,47 mg/10 g bahan; 15000 koloni/g.hari; 11,81 $\mathrm{mm} / \mathrm{s}$; dan 4,77. Hasil uji organoleptik terhadap aroma, rasa, warna, dan tekstur menunjukkan bahwa secara berturut-turut sebanyak 25,$71 ; 15,71 ; 65,71$ dan $55,71 \%$ panelis yang menyukai manisan tomat cherry dengan edible coating antimikroba. Hal ini berati bahwa manisan tomat cherry dengan edible coating antimikroba masih dapat diterima oleh panelis di hari penyimpanan ke-59.

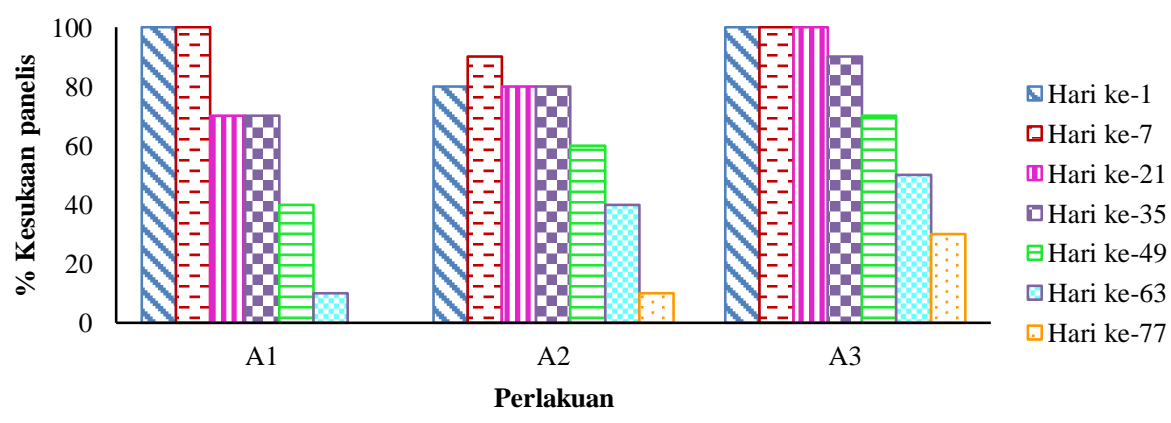

Gambar 8. Perubahan \% kesukaan panelis terhadap tekstur manisan tomat cherry selama penyimpanan 


\section{Saran}

Pada penelitian ini penggunaan minyak kayu manis dengan konsentrasi $0,6 \%$ memiliki rasa yang kurang disukai oleh panelis. Diharapkan pada penelitian selanjutnya, dilakukan optimasi kembali penggunaan konsentrasi minyak kayu manis untuk menghasilkan rasa yang disukai, namun dapat menghambat khamir yang merusak produk.

\section{DAFTAR PUSTAKA}

Agus P, Widdi U, dan Isyuniarto. 2007. Pengaruh lama waktu ozonisasi terhadap umur simpan buah tomat (Lycopersicum esculentum Mill). Pusat Teknologi Akselerator dan Proses Bahan: 237-239.

Begum SA, Faiaz M, Ahmed, Rahman MM. 2009. Effect of cooking temperature and storage period on preservation of water soluble vitamin $\mathrm{C}$ content in Citrus macroptera and Moringa oleifera lunk. Asian Journal Food Agroind 2(3):255-261.

Buckle KA, Edwards RA, Fleet GH, Wootton M. 2010. Food Science. Penerjemah Hari Purnomo dan Adiono dalam Ilmu Pangan. Jakarta: Universitas Indonesia.

Deák T. 2008. Handbook of Food Spoilage Yeasts. Second Edition. CRC Press. Boca Raton.

Ersoy B dan Ozeren A. 2009. The effect of cooking methods on mineral and vitamin contents of African catfish. Food Chemistry 115(2):419422.

Febriansah R dan Luthfia I. 2009. Tomat (Solanum Lycopersicum L.) sebagai Agen Kemopreventif Potensial. Fakultas Farmasi Universitas Gadjah Mada. Yogyakarta.

Febriyanti N, Wiharto M, dan Lahming. 2018. Pengaruh lama pengeringan dan berbagai jenis gula terhadap kualitas manisan tomat (Licopersium esculentum). Jurnal Pend Teknol Pertan 4:86-94.

Garber LL, Hyatt EM, dan Starr RG. 2000. The effect of food color an perceived flavor. Journal Mark Theory and Pract. 59-70.

Hasanah U. 2009. Pemanfaatan gel lidah buaya sebagai edible coating untuk memperpanjang umur simpan paprika (Capsicum annum varietas Sunny). [Tesis]. Bogor: Institut Pertanian Bogor.

Harianingsih. 2010. Pemanfaatan limbah cangkang kepiting menjadi kitosan sebagai bahan pelapis (Coater) pada buah stroberi. [Tesis]. Semarang: Universitas Diponegoro.

Hatmi RU, Cahyaningrum N, dan Siswanto N. 2014. Pemanfataan hasil pekarangan dalam mendukung pertanian organik. Prosiding Seminar Nasional Pertanian Organik. Bogor 18-19 Juni 2014.

Helmiyesi, Hastuti RB, dan Prihastanti E. 2008. Pengaruh lama penyimpanan terhadap kadar gula dan Vitamin C pada buah jeruk siam
(Citrus nobilis var. Microcarpa). Buletin Anatomi dan Fisiologi 16(2): 33-37.

Jayaraman KS dan Gupta DKD. 2006. Drying of Fruits And Vegetables. Di dalam: Mujumdar AS (Ed.). Handbook of Industrial Drying. Second Edition Revised and Expanded. London: Taylor and Francis Group,.

Mu'nisa A. 2012. Analisis kadar likopen dan uji aktivitas antioksi dan pada tomat asal Sulawesi Selatan. Jurnal Bionature. 13 (1): 62-66.

Nurdjanah S, Susilawati, dan Subatini MR. 2007. Prediction of cassava starch content at different stages of maturity using penetrometer. Jurnal Teknologi Industri Hasil Pertanian. 12: 2.

Rodriguez A, Nerin C, dan Battle R. 2008. New cinnamon-based active paper packaging against Rhizopus stolonifer food spoilage. Journal Agric Food Chem. 56(15):6364.

Safitri N, Sunarti TC, dan Meryandini A. 2016. Formula media pertumbuhan bakteri asam laktat Pediococcuspentosaceus menggunakan Substrat Whey Tahu. Jurnal Sumberdaya Hayati. 2(2):31-38.

Santoso B, Saputra D, dan Pambayun R. 2004. Kajian teknologi edible coating dari pati dan aplikasinyauntukpengemas primer lempok durian. Jurnal Teknologi Industri Pangan. 15(3):239-244.

Sartika R. 2010. Pengaruh Suhu dan Kelembaban Udara Terhadap Shelf-Life Dan Karakteristik Buah Manggis (Garcinia mangostana L.) Selama Pemyimpanan. Bogor: Fakultas Pertanian. IPB.

Suprapti ML. 2003. Manisan Kering Jambu Mete. Penerbit Kanisius. Yogyakarta.

Sumardiono S, Basri M, dan Sihombing RP. 2009. Analisis sifat-sifat psiko-kimia buah tomat (Lycopersicon esculentum) jenis tomat apel, guna peningkatan nilai fungsi buah tomat sebagai komoditi pangan lokal. Jurnal Penelitian.

Toor RK dan Savage GP. 2006. Changes in major antioxidant components of tomatoes during post-harvest storage. Journal Food Chem. 99:724-727.

Wang SY, Chen PF, dan Chang ST. 2005. Antifungal activities of essential oils and their constituents from indigenous cinnamon (Cinnamomum osmophloeum) leaves againts wood decay fungi. Bioresource Technology. 96(7): 813-818.

Wisudawaty P, Sugiarto, dan Pandji C. 2012. Application vegetable oil as a coating on the freez slices carrot (daucus carrota) and the quality changes during storage. E-JurnalAgroindustri Indonesia. 1(1):25-30

Wisudawaty P, Yuliasih I, dan Haditjaroko L. 2016. Pengaruh edible coating terhadap kapasitas air terikat sekunder dan tersier manisan tomat cherry selama penyimpanan. Jurnal Teknologi Industri Pertanian 26(3): 301-310. 